\title{
EFFECTS OF NOREPINEPHRINE ON UPTAKE AND OXIDATION OF PLASMA FREE FATTY ACIDS IN COLD-ACCLIMATED RATS
}

\author{
Kiyoshi Moriya, * Hiroshi Maekubo,** and Tsutomu Hiroshige \\ Department of Physiology, Hokkaido University School of Medicine, \\ Sapporo, 060 Japan
}

\begin{abstract}
In order to know the mode of action of norepinephrine in enhanced utilization of plasma free fatty acids (FFA) in cold acclimation, albumin-bound ${ }^{14} \mathrm{C}$-palmitate was infused intravenously at a constant rate into cold- and warm-acclimated rats under pentobarbital anesthesia with and without norepinephrine infusion. Rectal temperature, $\mathrm{CO}_{2}$ output and plasma FFA, from which the rates of FFA uptake and oxidation were calculated, were determined simultaneously. Similar fractions, that is, 7 and $5 \%$ of the total uptake of plasma FFA by the tissue were immediately oxidized in both cold- and warm-acclimated rats, respectively. Norepinephrine infusion caused a significant increase in all the parameters examined. In addition, during hormone infusion the percentage of FFA uptake oxidized was elevated from $22 \%$ in control to $50 \%$ in coldacclimated rats. This increment was accompanied with greater increases in rectal temperature and $\mathrm{CO}_{2}$ output. Similarly, in functionally eviscerated cold-acclimated rats, norepinephrine induced a greater increase in the percentage of FFA uptake oxidized than in eviscerated controls. These results indicate that although the FFA uptake was increased simultaneously norepinephrine infusion caused a more marked acceleration of the oxidation of plasma FFA in the cold-acclimated rats than in control rats.
\end{abstract}

Enhanced nonshivering thermogenesis in cold-acclimated animals is mainly mediated by norepinephrine (HSIEH and CARLSON, 1957; HSIEH et al., 1957). Norepinephrine mobilizes free fatty acids (FFA) from white adipose tissue more efficiently in cold-acclimated animals (THERRIAUlt et al., 1969). However, few

\footnotetext{
Received for publication July 29, 1977

* Present address: Laboratory of Health Science, Faculty of Education, Hokkaido University, Sapporo, 060 Japan

** Present address: Department of Internal Medicine, Hokkaido University School of Medicine, Sapporo, 060 Japan

森谷 絜, 前久保博士，広重 力
} 
observations have been made on direct analysis of norepinephrine action on the in vivo oxidation of plasma FFA to $\mathrm{CO}_{2}$ in cold-acclimated animals. MASIRONI and DePocas (1961) reported that the oxidation rate of plasma FFA in cold-acclimated rats was higher in an environment at $6^{\circ} \mathrm{C}$ than at $30^{\circ} \mathrm{C}$, but these values remained similar in magnitude to those in warm-acclimated rats.

In a previous study in this laboratory (MORIYA et al., 1974), it was shown that norepinephrine induced a higher uptake of plasma FFA by the tissue in coldacclimated rats even with lower plasma FFA concentrations and a greater elevation in the rectal temperature than in warm-acclimated rats. In both groups, a significant positive correlation was obtained between the concentration and the uptake, respectively. It is known that the uptake of plasma FFA by the tissue is controlled, on the one hand, by its concentration according to the mass action effect (ARMSTRONG et al., 1961a, b) and by changes in the status of energy requirement (IsSEKUTz et al., 1964; MinAIRE et al., 1973) on the other. Therefore, it was assumed (MORIYA et al., 1974) that cold acclimation brought about changes in the energy status so that norepinephrine might activate directly or indirectly greater FFA uptake.

The purpose of the present study was to decide whether the primary site of action of norepinephrine lies in the promotion of FFA uptake or not. To this end, the oxidation rate of ${ }^{14} \mathrm{C}$-palmitate to ${ }^{14} \mathrm{CO}_{2}$ was determined simultaneously with its uptake measurement. The result obtained were compared with those in warmacclimated rats and a possible site of action of the hormone was discussed.

\section{MATERIALS AND METHODS}

Male Wistar rats, weighing from 170 to $400 \mathrm{~g}$ (average $300 \mathrm{~g}$ ), were used. The animals were acclimated to cold by exposing them to $5^{\circ} \mathrm{C}$ for 4 to 6 weeks and control rats were kept at $22^{\circ} \mathrm{C}$. They were provided with water and a rat chow (Oriental MF) ad libitum.

After $18 \mathrm{hr}$ fasting, rats were moved from rearing rooms to an experimental room at $25^{\circ} \mathrm{C}$ one hour prior to anesthesia with pentobarbital $(70 \mathrm{mg} / \mathrm{kg}$ body weight, i.p.). When anesthesia of longer duration was required, urethane $(1.5 \mathrm{~g} /$ $\mathrm{kg}$ body weight, i.p.) was used instead. The animal was placed in a chamber with minimal dead space. The chamber was connected proximally to air and distally to a respirator pump. The rate of flow of effluent air was approximately $500 \mathrm{ml} / \mathrm{min}$. A continuous infusion of ${ }^{14} \mathrm{C}$-palmitate-albumin complex was given throughout the experiment via the right femoral vein using a constant infusion pump which delivered $14 \mu \mathrm{l}$ of solution $\left({ }^{14} \mathrm{C}: 5 \mathrm{~m} \mu \mathrm{Ci}\right)$ per min through an indwelling polyethylene catheter. The first blood sample $(1.2 \mathrm{ml})$ was drawn from the jugular vein into heparinized syringes at $20 \mathrm{~min}$ after the start of continuous infusion of ${ }^{14} \mathrm{C}$-palmitate. Immediately after the sampling infusion of norepinephrine (Sankyo Pharmaceut. Co.) was started concurrently with ${ }^{14} \mathrm{C}$-palmitate infusion via another 
femoral vein. Norepinephrine was infused at rates of $0.25,1.0,2.0$ and $4.0 \mu \mathrm{g} / \mathrm{min}$ (the volume: $28 \mu \mathrm{l} / \mathrm{min}$ ) for $20 \mathrm{~min}$. The second blood sample was drawn $20 \mathrm{~min}$ after the start of norepinephrine infusion. These samples were used for measurements of plasma FFA concentration and its radioactivity. The effluent air samples were directed through U-tubes containing $5 \mathrm{ml}$ of $0.5 \mathrm{~m}$ hyamine in methanol for five min before the first and the second blood samplings, respectively. This trapping solution was used for measurement of $\mathrm{CO}_{2}$ expiration and its radioactivity.

A plateau in specific activity (SA) of FFA was obtained within the first $10 \mathrm{~min}$ after ${ }^{14} \mathrm{C}$-palmitate infusion irrespective of norepinephrine infusion and thereafter it remained almost constant during the following $40 \mathrm{~min}$ period (Fig. 1). Under the steady state condition, the infusion rate of ${ }^{14} \mathrm{C}$-palmitate divided by SA of FFA represents turnover rate of plasma FFA (ARMSTRONG et al., 1961a). Since this value indicates uptake rate in the steady state, we used the term "uptake" instead of

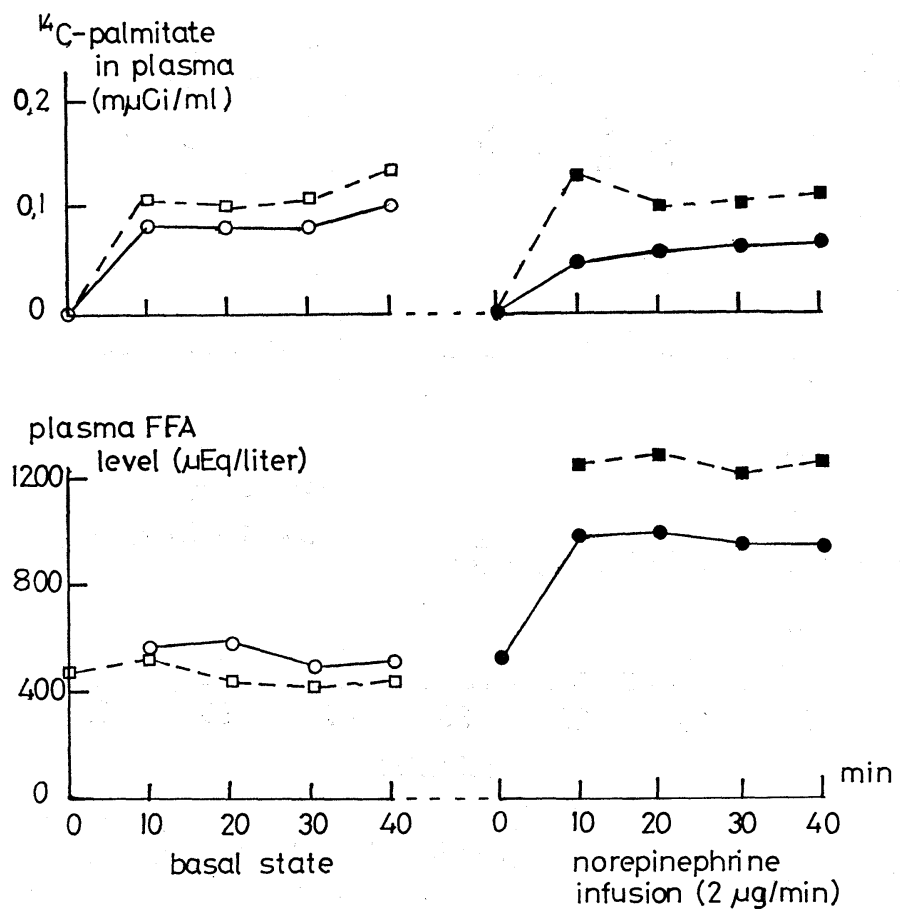

Fig. 1. Time course of changes in the plasma FFA concentration and ${ }^{14} \mathrm{C}$-palmitate in plasma during continuous infusion of ${ }^{14} \mathrm{C}$-palmitate-albumin complex into warm- $(\square, \boldsymbol{\square})$ and cold-acclimated rats $(O, \bullet)$ under pentobarbital anesthesia $(70 \mathrm{mg} / \mathrm{kg}$ body weight $)$. Open symbols represent values in the basal state and closed symbols values under norepinephrine infusion at a rate of $2 \mu \mathrm{g} / \mathrm{min}$. Infusion of ${ }^{14} \mathrm{C}$-palmitate-albumin complex at a rate of $1.42 \mathrm{~m} \mu \mathrm{Ci} / \mathrm{min}$ started at $0 \mathrm{~min}$. Each value was analyzed from $0.6 \mathrm{ml}$ of blood. Total blood loss was within $3 \mathrm{ml}$ per rat. 
turnover rate in the following text. During the steady state with constant $\mathrm{CO}_{2}$ output, the labeled substrate is oxidized to ${ }^{14} \mathrm{CO}_{2}$ which becomes mixed with the unlabeled bicarbonate pool. The SA of $\mathrm{CO}_{2}\left(\mathrm{CO}_{2} \mathrm{SA}\right)$ as well as the total $\mathrm{CO}_{2}$ output rises in a form of exponential curve approaching an asymptotic value.

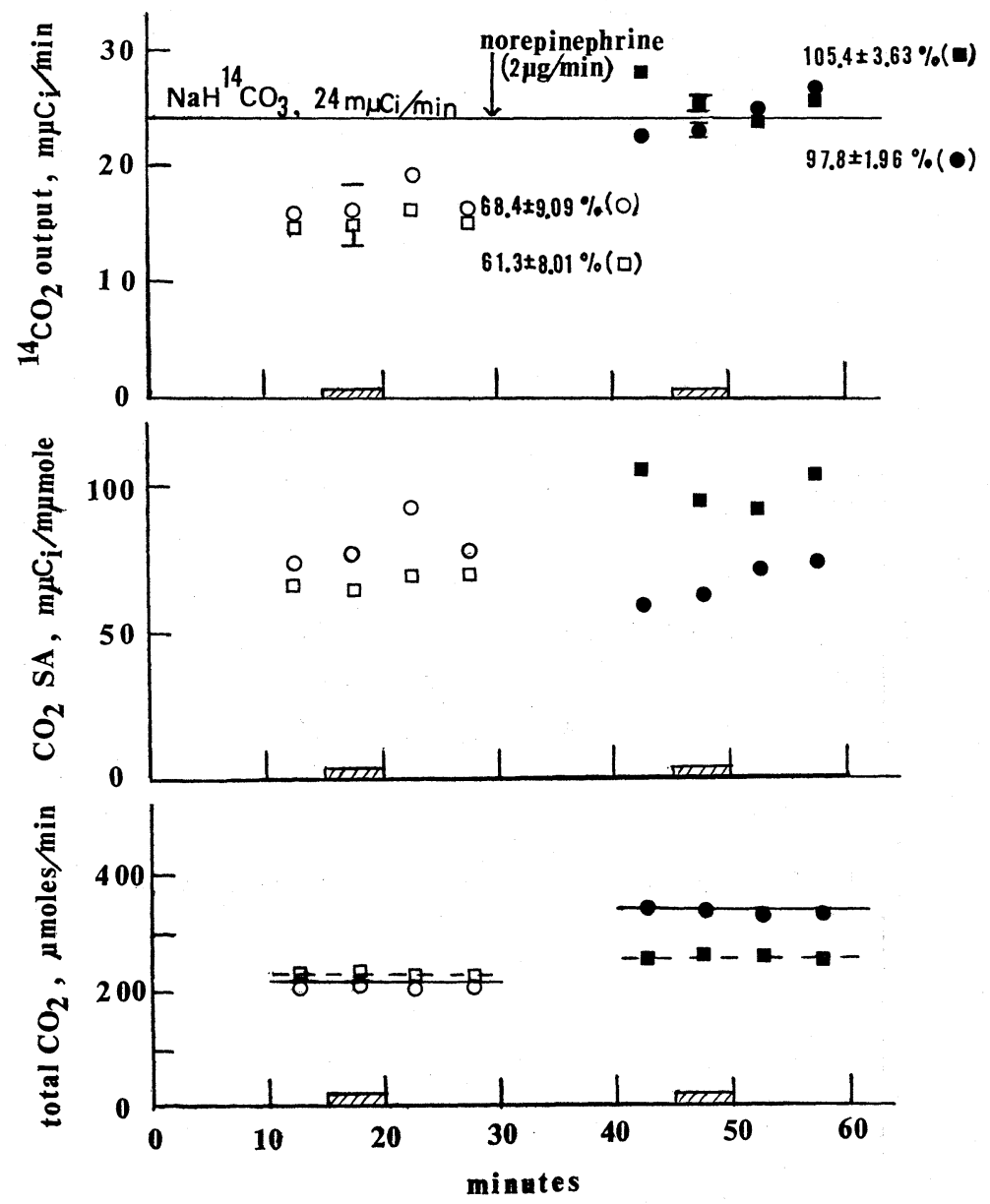

Fig. 2. Time course of recovery of ${ }^{14} \mathrm{CO}_{2}$ in terms of total $\mathrm{CO}_{2}, \mathrm{CO}_{2} \mathrm{SA}$ and ${ }^{14} \mathrm{CO}_{2}$ output in the exhaled air during the constant infusion of $\mathrm{NaH}^{14} \mathrm{CO}_{3}$ in warm- $(\square, \square)$ and coldacclimated rats $(\mathrm{O}, \bullet)$. Open symbols represent values under the basal state and closed symbols those under norepinephrine infusion. Infusion of $\mathrm{NaH}^{14} \mathrm{CO}_{3}$ at a rate of $24 \mathrm{~m} \mu \mathrm{Ci} / \mathrm{min}$ started at $0 \mathrm{~min}$. Hatched areas on the abscissa indicate the sampling periods that correspond to specific pairs of data above them. The infusion of norepinephrine $(2 \mu \mathrm{g} / \mathrm{min})$ intervened as described in the text. This combination of the sampling periods was exclusively used throughout the experiments in this study except this series of experiments with $\mathrm{NaH}^{14} \mathrm{CO}_{3}$ infusion. Numbers in the top figure are means $\pm \mathrm{SE}$ of percentage recovery of $\mathrm{NaH}^{14} \mathrm{CO}_{3}$ for five warm- $(\square, \square)$ and five cold-acclimated rats $(O$, $\bullet)$, respectively. 
It is assumed that in small animals where the fractional turnover rate of the bicarbonate pool is high (ARMSTRONG et al., 1948; SKIPPER et al., 1951), the measured value of $\mathrm{CO}_{2} \mathrm{SA}$ is similar to the asymptote $\mathrm{CO}_{2} \mathrm{SA}_{t=\infty}$. To ascertain this assumption, $\mathrm{NaH}^{14} \mathrm{CO}_{3}$ (New England Nuclear Corp., SA: $50 \mathrm{Ci} / \mathrm{mol}$ ) was infused intravenously at a constant rate under the same experimental conditions as used in the ${ }^{14} \mathrm{C}$-palmitate infusion. The time course of average $\mathrm{NaH}^{14} \mathrm{CO}_{3}$ output as ${ }^{14} \mathrm{CO}_{2}$ in warm- and cold-acclimated rats is shown in Fig. $2 .{ }^{14} \mathrm{CO}_{2}$ output was less than the rate of infusion of $\mathrm{NaH}^{14} \mathrm{CO}_{3}$ in the basal state. To find the proper condition, $\mathrm{NaH}^{14} \mathrm{CO}_{3}$ infusion of longer duration (up to $140 \mathrm{~min}$ ) was tried in rats anesthetized with urethane, but the results obtained were essentially similar to those shown in Fig. 2. Hence calculations of the asymptotic values were corrected accordingly.

The asymptotic $\mathrm{CO}_{2} \mathrm{SA}_{t=\infty}$ was divided by the SA of FFA and multiplied by 17 to obtain the percentage of $\mathrm{CO}_{2}$ derived from the immediate oxidation of plasma FFA (PAUL and Holmes, 1973). The rate of plasma FFA oxidation was calculated from the percentage of $\mathrm{CO}_{2}$ and respiratory $\mathrm{CO}_{2}$ output (PAUL and HolmES, 1973).

${ }^{14} \mathrm{C}$-U-palmitate or ${ }^{14} \mathrm{C}$-1-palmitate (New England Nuclear Corp., SA: 500 or $52 \mathrm{Ci} / \mathrm{mol}$, respectively) was prepared for infusion by dissolving its sodium salt in distilled water and diluting with an equal volume of $10 \%$ solution of bovine serum albumin (Armour Pharmaceut. Co., Fraction V).

Plasma FFA concentration was determined by the method of DuNCOMBE (1963). Radioactivity in the FFA fraction which was isolated by the method of STEINBERG et al. (1964) was counted with a scintillation spectrometer. Total $\mathrm{CO}_{2}$ output and its radioactivity were determined according to the method of FREDRICKSON and ONO (1958): One milliliter of the trapping solution of expired $\mathrm{CO}_{2}$ was titrated with $0.1 \mathrm{~N} \mathrm{HCl}$ for total $\mathrm{CO}_{2}$ determination. One milliliter of the trapping solution was also added to the scintillator which consisted of 2,5-diphenyloxasole (PPO, $4 \mathrm{~g} /$ liter of toluene) and 1, 4-di-2 (5-phenyloxazolyl)-benzene (POPOP, $0.1 \mathrm{~g} /$ liter of toluene).

Rectal temperature was measured by inserting a thermistor to a depth of $5 \mathrm{~cm}$ from the anus in a room with a temperature of $25^{\circ} \mathrm{C}$ at $0,10,20,30$ and $40 \mathrm{~min}$ after the start of the ${ }^{14} \mathrm{C}$-palmitate-albumin complex infusion.

Functionally eviscerated rats were prepared by ligating the rectal colon, superior mesenteric and coeliac arteries and portal vein. Before the operation, glucose was subcutaneously injected in a dose of $100 \mathrm{mg} / \mathrm{kg}$ body weight in order to maintain blood glucose at a nearly constant level. In these rats the first blood sample was drawn $15 \mathrm{~min}$ after ${ }^{14} \mathrm{C}$-palmitate infusion and rectal temperature was measured at a depth of $3 \mathrm{~cm}$ from the anus.

Regression equations were obtained by the method of least squares. Student's $t$ test was used for the comparison of two values. 


\section{RESULTS}

\section{Thermogenic responses to norepinephrine infusion}

In the basal state, before the intravenous infusion of various doses of norepinephrine, the average value of rectal temperature was $34.80 \pm 0.20^{\circ} \mathrm{C}(n=20)$ in warm- and $35.04 \pm 0.22(n=20)$ in cold-acclimated rats and it lowered by 1.21 $\pm 0.95^{\circ} \mathrm{C}$ and $1.15 \pm 0.76$, respectively, during following $20 \mathrm{~min}$ of saline infusion. Norepinephrine infusion at a rate of $0.25 \mu \mathrm{g} / \mathrm{min}$ allowed a gradual lowering of rectal temperature in cold- as well as warm-acclimated rats, but infusions at rates of $1.0,2.0$ and $4.0 \mu \mathrm{g} / \mathrm{min}$ resulted in significant elevation of rectal temperature $+0.98 \pm 0.26^{\circ} \mathrm{C}(n=4),+1.53 \pm 0.44(n=6)$ and $+1.19 \pm 0.33(n=4)$, respectively, in cold-acclimated rats, but not in warm-acclimated controls.

Average value of respiratory $\mathrm{CO}_{2}$ expiration rates before the infusion of norepinephrine was $43 \pm 2.4 \mu \mathrm{mol} / \mathrm{min} / 100 \mathrm{~g}$ body weight $(n=20)$ in cold-acclimated rats (Table 1). Norepinephrine infusion caused an increase in respiratory $\mathrm{CO}_{2}$ output in both groups. At doses of more than $1.0 \mu \mathrm{g} / \mathrm{min}, \mathrm{CO}_{2}$ output was greater in cold- than in warm-acclimated groups.

Table 1. Effects of norepinephrine (NE) infusion on the respiratory $\mathrm{CO}_{2}$ outputs in warm- and cold-acclimated rats under pentobarbital anesthesia.

\begin{tabular}{cccccc}
\hline Group & $\begin{array}{c}\text { NE doses } \\
\text { in } \mu \mathrm{g} / \mathrm{min} \\
\text { (No. of } \\
\text { rats) }\end{array}$ & Before & After & $\begin{array}{c}\text { Paired } \\
\text { differences }\end{array}$ & $p^{\dagger}$ \\
\hline \multirow{6}{*}{ Warm-acclimated rats } & $0.25(6)$ & $30 \pm 5.2$ & $41 \pm 5.1$ & $11 \pm 3.4$ & $<0.05$ \\
& $1.0(4)$ & $28 \pm 3.7$ & $50 \pm 2.7$ & $25 \pm 2.8$ & $<0.01$ \\
& $2.0(6)$ & $34 \pm 3.6$ & $58 \pm 3.5$ & $24 \pm 4.8$ & $<0.01$ \\
& $4.0(4)$ & $31 \pm 3.8$ & $56 \pm 3.8$ & $26 \pm 6.3$ & $<0.05$ \\
\hline \multirow{6}{*}{ Cold-acclimated rats } & $0.25(6)$ & $41 \pm 2.6$ & $55 \pm 6.0$ & $13 \pm 5.0$ & $<0.05$ \\
& $1.0(4)$ & $48 \pm 7.0^{*}$ & $90 \pm 4.2^{* * *}$ & $42 \pm 3.4^{* *}$ & $<0.01$ \\
& $2.0(6)$ & $42 \pm 5.2$ & $114 \pm 8.3^{* * *}$ & $72 \pm 10.4^{* *}$ & $<0.001$ \\
& $4.0(4)$ & $41 \pm 5.9$ & $104 \pm 3.7^{* * *}$ & $63 \pm 8.9^{* *}$ & $<0.01$ \\
\hline
\end{tabular}

Means $\pm S E$. All values are expressed as $\mu \mathrm{mol} / \mathrm{min} / 100 \mathrm{~g}$ body weight. ${ }^{\dagger} p$ values for the paired differences. $* p<0.05, * * p<0.01, * * * p<0.001$ vs. warm-acclimated controls.

Significant positive correlations between $\mathrm{CO}_{2}$ expiration $(X)$ and rectal temperature $(Y)$ were observed in warm- and cold-acclimated groups. In these cases, corrections were made by adding the average change of rectal temperature (as detailed above) during saline infusion to each rectal temperature measured at the end (20 $\mathrm{min})$ of norepinephrine infusion. In warm-acclimated rats, the relation was given by $Y=0.029 X+34.0(n=40), r=0.359(p<0.05)$, in cold-acclimated rats by $Y=0.032 X+33.9(n=40), r=0.698(p<0.01)$. The regression coefficient and ordinate intercept of the line were not significantly different between these groups. 
Changes in the metabolism of plasma FFA during norepinephrine infusion

Changes in plasma FFA concentration and its uptake induced by norepinephrine infusion are illustrated in Fig. 3. The average basal values of plasma FFA concentration were $695 \pm 34 \mu \mathrm{Eq} /$ liter $(n=20)$ for warm- and $712 \pm 50 \quad(n=20)$ for the cold-acclimated group. As seen in this figure, increases in plasma FFA concentration in response to norepinephrine were less in cold- than in warmacclimated rats. The average value of uptake of plasma FFA for warm-acclimated controls was $2.65 \pm 0.15 \mu \mathrm{Eq} / \mathrm{min} / 100 \mathrm{~g}$ body weight $(n=20)$ and $3.13 \pm 0.19(n=20)$ for cold-acclimated rats, both values being not significantly different. Norepinephrine infusion in increasing doses caused increases in concentration and uptake of plasma FFA in both groups.

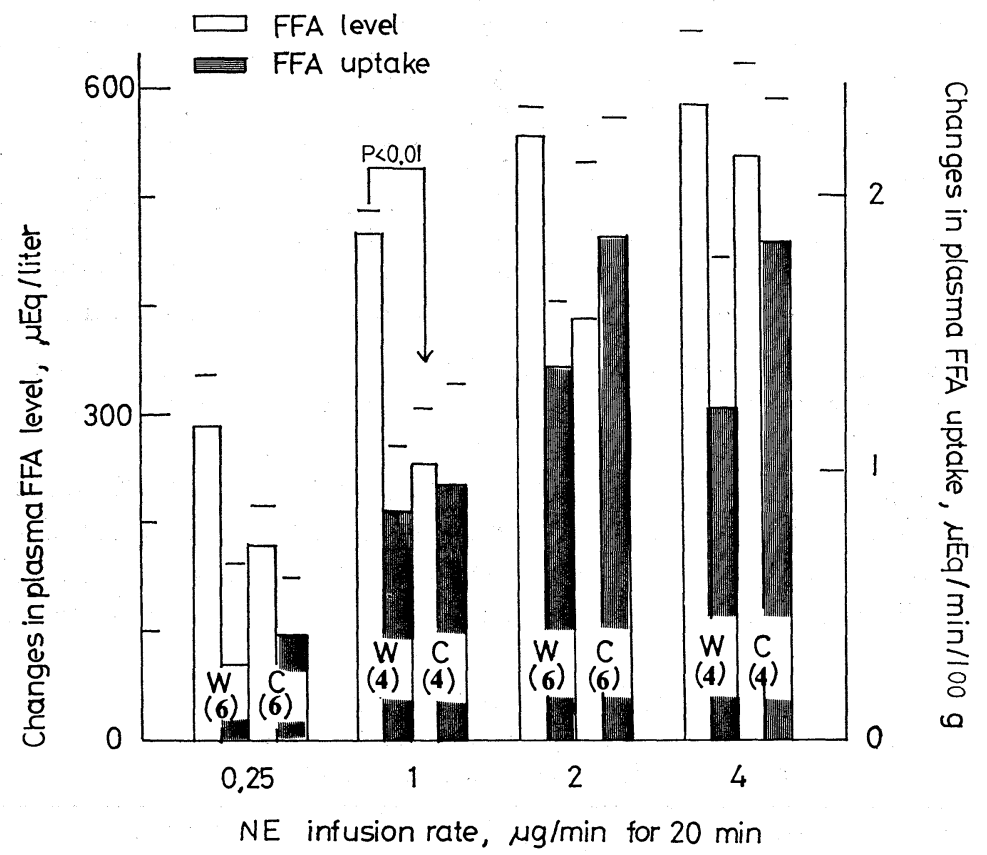

Fig. 3. Changes in plasma FFA concentration and its uptake following norepinephrine infusion. Norepinephrine doses are shown at the bottom along the abscissa. W stands for warm-acclimated, and $\mathrm{C}$ for cold-acclimated rats, accompanied by numbers of paired determinations. Bars on the top of columns represent SE of the means.

Between plasma FFA concentration $(X)$ and its uptake $(Y)$, significant positive correlation was obtained in both groups. The relations were given by $Y=0.031$ $X+1.05(n=40), r=0.713(p<0.01)$ in cold-acclimated rats and by $Y=0.019 X$ $+1.36(n=40), r=0.588(p<0.01)$ in controls. The FFA uptake increased linearly with the increasing FFA concentration in both groups, but the regression coefficient for cold-acclimated rats was significantly greater $(p<0.01)$ than that for controls. 
Oxidation rates of plasma FFA are shown in Table 2. An average basal value of oxidation rates of plasma FFA in cold-acclimated rats was $0.22 \pm 0.04 \mu \mathrm{Eq} / \mathrm{min} /$ $100 \mathrm{~g}$ body weight $(n=20)$ which was significantly larger $(p<0.05)$ than $0.12 \pm 0.01$ $(n=20)$ in warm-acclimated rats. Increasing doses of norepinephrine, up to $2.0 \mu \mathrm{g} / \mathrm{min}$, caused increased oxidation of plasma FFA in both groups, and the magnitude of change was greater in the former group than in the latter.

Table 2. Effects of norepinephrine (NE) infusion on the oxidation rates of plasma free fatty acids (FFA) in warm- and cold-acclimated rats under pentobarbital anesthesia.

\begin{tabular}{lccccc}
\hline \multicolumn{1}{c}{ Group } & $\begin{array}{c}\text { NE doses } \\
\text { in } \mu \mathrm{g} / \mathrm{min} \\
(\mathrm{No} \text { of rats) }\end{array}$ & Before & After & $\begin{array}{c}\text { Paired } \\
\text { differences }\end{array}$ & $p^{\dagger}$ \\
\hline \multirow{3}{*}{ Warm-acclimated } & $0.25(6)$ & $0.10 \pm 0.02$ & $0.36 \pm 0.07$ & $0.26 \pm 0.06$ & $<0.01$ \\
rats & $1.0(4)$ & $0.13 \pm 0.04$ & $0.67 \pm 0.04$ & $0.54 \pm 0.03$ & $<0.001$ \\
& $2.0(6)$ & $0.14 \pm 0.02$ & $0.96 \pm 0.12$ & $0.82 \pm 0.12$ & $<0.01$ \\
& $4.0(4)$ & $0.11 \pm 0.02$ & $0.79 \pm 0.21$ & $0.68 \pm 0.20$ & $<0.05$ \\
\hline \multirow{3}{*}{ Cold-acclimated } & $0.25(6)$ & $0.19 \pm 0.03$ & $0.53 \pm 0.06$ & $0.34 \pm 0.06$ & $<0.01$ \\
rats & $1.0(4)$ & $0.22 \pm 0.05$ & $1.74 \pm 0.41^{*}$ & $1.53 \pm 0.32^{*}$ & $<0.05$ \\
& $2.0(6)$ & $0.19 \pm 0.05$ & $2.44 \pm 0.32^{* *}$ & $2.25 \pm 0.32^{* *}$ & $<0.001$ \\
& $4.0(4)$ & $0.32 \pm 0.17$ & $1.90 \pm 0.08^{* *}$ & $1.58 \pm 0.21^{*}$ & $<0.01$ \\
\hline
\end{tabular}

Means $\pm \mathrm{SE}$ of the mean, expressed as $\mu \mathrm{Eq} / \mathrm{min} / 100 \mathrm{~g}$ body weight. ${ }^{\dagger} p$ values for the paired differences. $* p<0.05,{ }^{*} p<0.01 v s$. warm-acclimated controls.

Percentages of oxidation to uptake of plasma FFA were estimated in both groups (Table 3). The percentages were increased by various doses of norepinephrine in both groups, and the percentage increases were greater in cold- than in warm-acclimated groups. Percentages of $\mathrm{CO}_{2}$ derived from plasma FFA were

Table 3. Effects of norepinephrine (NE) on the ratio of oxidation rate to uptake rate of plasma free fatty acids (FFA) in warm- and coldacclimated rats under pentobarbital anesthesia.

\begin{tabular}{lccccc}
\hline \multicolumn{1}{c}{ Group } & $\begin{array}{c}\text { NE doses } \\
\text { in } \mu \mathrm{g} / \mathrm{min} \\
(\text { No. of rats) }\end{array}$ & $\begin{array}{c}\text { Before } \\
(\%)\end{array}$ & $\begin{array}{c}\text { After } \\
(\%)\end{array}$ & $\begin{array}{c}\text { Paired } \\
\text { differences } \\
(\%)\end{array}$ & $p^{\dagger}$ \\
\hline \multirow{3}{*}{ Warm-acclimated } & $0.25(6)$ & $3.3 \pm 0.6$ & $11.0 \pm 1.7$ & $7.7 \pm 1.7$ & $<0.01$ \\
$\quad 1.0(4)$ & $5.6 \pm 1.8$ & $22.1 \pm 2.6$ & $16.3 \pm 3.0$ & $<0.05$ \\
rats & $2.0(6)$ & $6.4 \pm 0.8$ & $26.2 \pm 2.1$ & $19.8 \pm 2.6$ & $<0.001$ \\
& $4.0(4)$ & $3.7 \pm 0.5$ & $18.1 \pm 3.0$ & $14.4 \pm 2.9$ & $<0.05$ \\
\hline \multirow{3}{*}{ Cold-acclimated } & $0.25(6)$ & $5.4 \pm 0.9$ & $13.5 \pm 2.3$ & $8.1 \pm 2.0$ & $<0.01$ \\
rats & $1.0(4)$ & $7.7 \pm 1.7$ & $49.5 \pm 7.9^{*}$ & $41.9 \pm 6.7^{*}$ & $<0.01$ \\
& $2.0(6)$ & $5.9 \pm 1.4$ & $54.0 \pm 12.8^{*}$ & $48.1 \pm 11.6^{*}$ & $<0.01$ \\
& $4.0(4)$ & $11.8 \pm 4.9$ & $43.9 \pm 7.4$ & $31.7 \pm 5.3^{*}$ & $<0.01$ \\
\hline
\end{tabular}

Means \pm SE. ${ }^{\dagger} p$ values for the paired differences. $* p<0.05 v s$. warm-acclimated controls. 
elevated by various doses of norepinephrine in both groups. The change at each dose in cold-acclimated rats was not significantly different from that in controls. As a whole, they were increased from $6.6 \pm 0.5 \%$ to $22.3 \pm 7.9$ in warm-acclimated rats $(n=20)$ and from $8.7 \pm 1.2$ to $29.2 \pm 3.2$ in cold-acclimated rats $(n=20)$.

The amount of FFA oxidized and percentage of $\mathrm{CO}_{2}$ derived from plasma FFA increased linearly with increasing FFA concentration in both warm- and coldacclimated groups, but at any equivalent concentrations, the values in cold-acclimated rats were considerably higher than those in the controls. The amount of FFA oxidized also increased linearly with the increasing FFA uptake in both groups. The correlations between uptake $(X$, in $\mu \mathrm{Eq} / \mathrm{min} / 100 \mathrm{~g})$ and oxidation rates $(Y$, in $\mu \mathrm{Eq} / \mathrm{min} / 100 \mathrm{~g})$ of plasma FFA were given by $Y=0.404 X-0.588 \quad(n=40)$, $r=0.468(p<0.01)$ in cold-acclimated rats and by $Y=0.268 X-0.425 \quad(n=40)$, $r=0.690(p<0.01)$ in controls. The regression coefficient for cold-acclimated rats was significantly greater $(p<0.01)$ than that for the controls.

\section{Relationship between thermogenesis and FFA metabolism}

$\mathrm{CO}_{2}$ expiration, as an indicator of thermogenesis, increased linearly with increases in oxidation rate of plasma FFA (Fig. 4A). The regression coefficient for cold-acclimated rats was essentially similar to that for the controls. On the other hand, the regression coefficient between $\mathrm{CO}_{2}$ output and uptake of plasma FFA for cold-acclimated rats was greater $(p<0.01)$ than that for the controls, although correlations were significant in either group (Fig. 4B).

\section{Thermogenesis and FFA metabolism in functionally eviscerated rats}

The evisceration caused the lowering of rectal temperature, of respiratory $\mathrm{CO}_{2}$ expiration and plasma FFA metabolism in terms of oxidation rate, percentage of FFA uptake oxidized (Table 4) and percent $\mathrm{CO}_{2}$ from plasma FFA. In eviscerated rats, as in intact animals, norepinephrine-induced elevation in plasma FFA concentration, its oxidation rate, percent of FFA uptake oxidized and percent $\mathrm{CO}_{2}$ from plasma FFA was in parallel with the elevation of rectal temperature and $\mathrm{CO}_{2}$ output. The magnitude of elevation of each parameter, except FFA concentration, was greater in eviscerate cold-acclimated rats than in eviscerate controls.

When $\mathrm{NaH}^{14} \mathrm{CO}_{3}$ was infused intravenously at a constant rate, recovery of ${ }^{14} \mathrm{C}$ as ${ }^{14} \mathrm{CO}_{2}$ in the basal state was $38 \%$ in eviscerate warm- and $33 \%$ in eviscerate cold-acclimated rats. It increased under norepinephrine infusion $(2 \mu \mathrm{g} / \mathrm{min}$ for $20 \mathrm{~min}$ ) to $76 \%$ in the former and $86 \%$ in the latter. Accordingly, $\mathrm{CO}_{2} \mathrm{SA}_{t=\infty}$ was corrected in the eviscerate groups.

\section{DISCUSSION}

Enhanced thermogenesis is one of the characteristics of cold acclimation. In a previous study in this laboratory (MorIYA et al., 1974), changes in rectal temperature were used as a measure of enhanced heat production under norepinephrine 

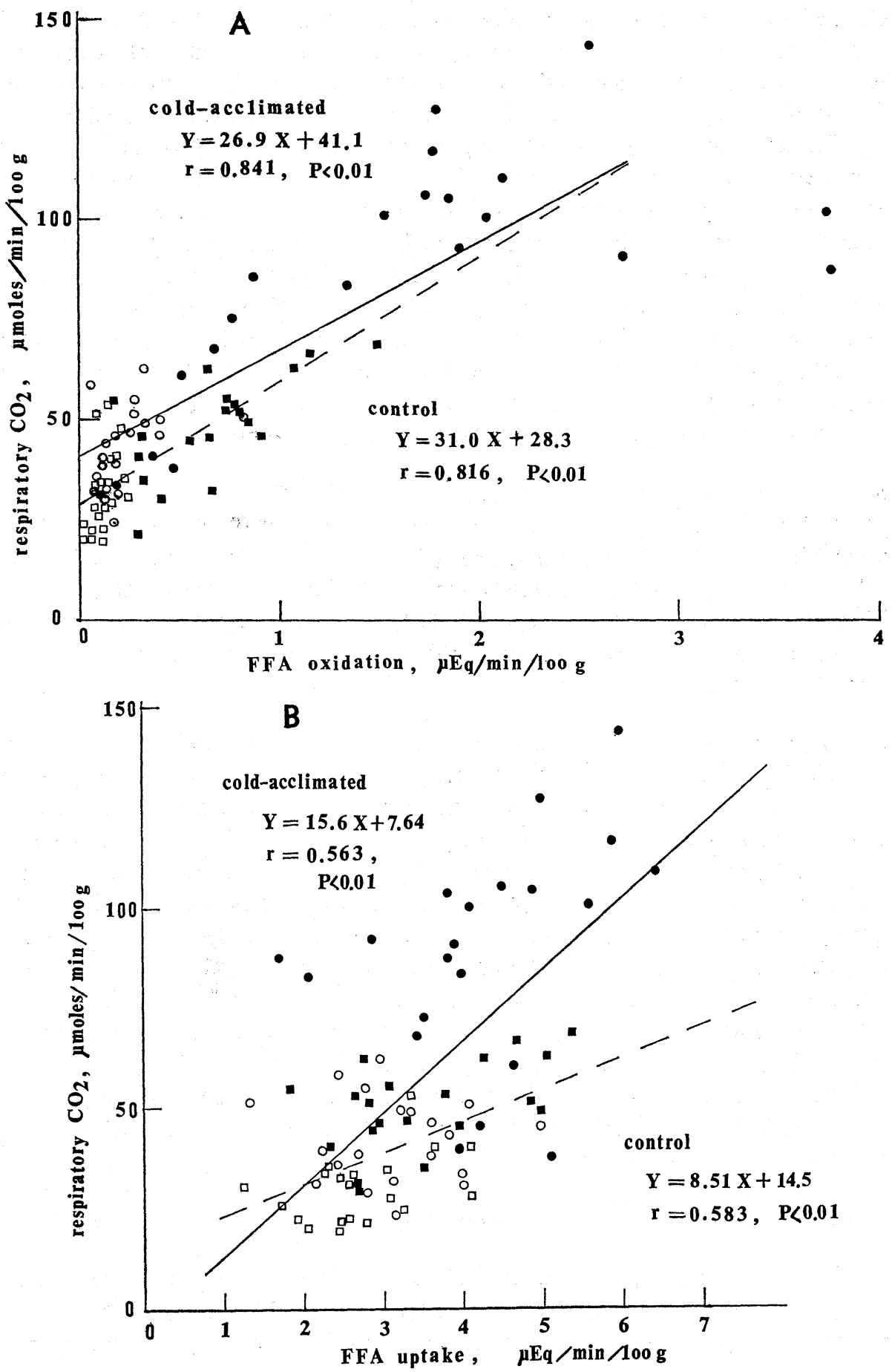

Fig. 4 
Table 4. The metabolism of plasma free fatty acids (FFA) in eviscerated preparations in the basal state and during norepinephrine infusion

$(2 \mu \mathrm{g} / \mathrm{min})$ for $20 \mathrm{~min}$ under pentobarbital anesthesia.

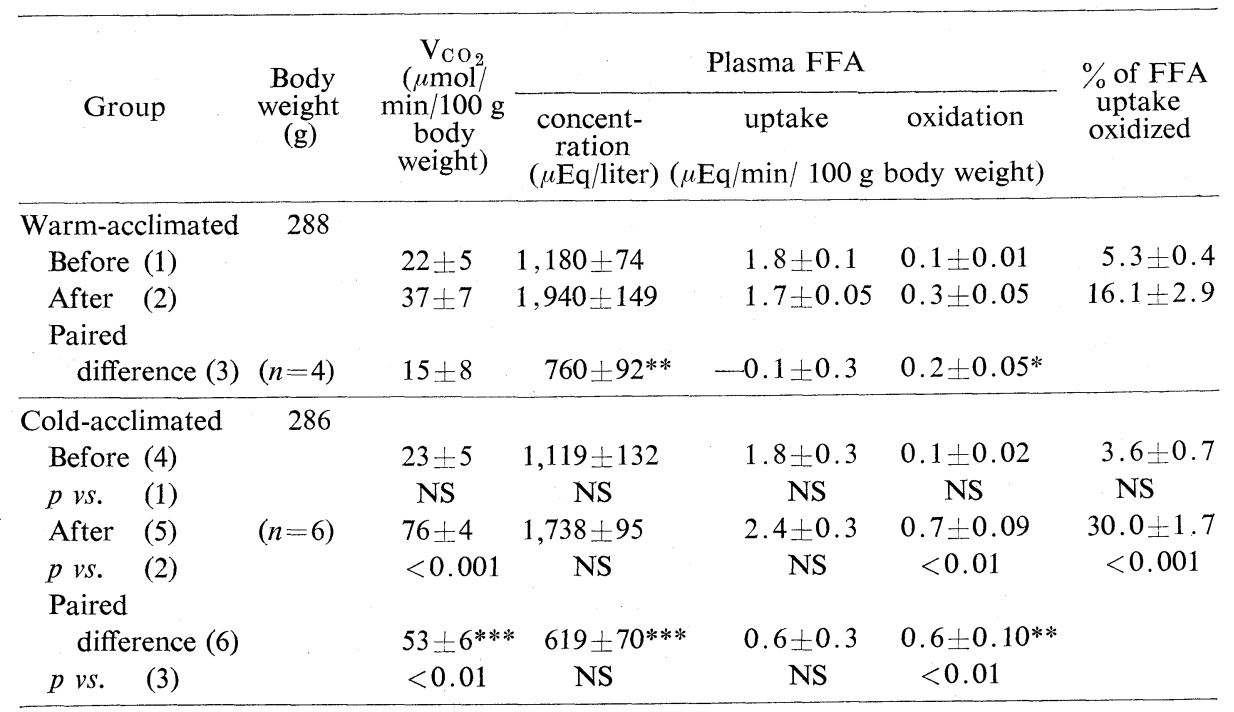

Means \pm SE. $\quad * p<0.05, \quad * * p<0.01, \quad * * * p<0.001$.

load. Based on the correlation analysis between rectal temperature and logarithm concentration or uptake of plasma FFA, it was inferred that an increase in the capacity of uptake rather than oxidation of plasma FFA occurs in cold-acclimated rats. Since the rectal temperature is a balance between heat production and loss, it is not a direct indicator of heat production.

Using $\mathrm{CO}_{2}$ expiration as an indicator of calorigenesis, it was confirmed in this study that norepinephrine enhanced heat production and its effect was greater in cold- than in warm-acclimated rats. It was also shown that the regression coefficient between $\mathrm{CO}_{2}$ output and plasma FFA oxidation rate was essentially similar in magnitude in both groups (Fig. 4A). The result indicates that the $\mathrm{CO}_{2}$ expiration rate is a direct reflection of FFA oxidation irrespective of animal's energy status such as aquisition of cold acclimation. It should be noted, however, that although the rate of $\mathrm{CO}_{2}$ expiration was correlated well with the uptake, the $\mathrm{CO}_{2}$ expiration rate was evidently greater in the cold- than in the warm-acclimated rats when compared at the same uptake rate (Fig. 4B). The result indicates that enhanced $\mathrm{CO}_{2}$ production (i.e., enhanced heat production) in cold-acclimated rats cannot be explained by simple enhancement in the uptake of FFA, the conclusion being in discord with the previous one (MoRIYA et al., 1974) which was obtained

Fig. 4. Interrelationships between respiratory $\mathrm{CO}_{2}$ output and plasma FFA oxidation (A) and its uptake rate (B) in warm- $(\square, \boldsymbol{\square})$ and cold-acclimated rats $(\bigcirc, \bullet)$ under the basal state (open symbols) and during norepinephrine infusion (closed symbols). 
with an indirect indicator of thermogenesis. Thus, the magnitude of oxidation, instead of uptake, of plasma FFA is of direct importance.

Average value of oxidation rates before norepinephrine infusion was significantly larger in cold- than in warm-acclimated rats (Table 2). The result is consistent with the finding that liver slices from cold-acclimated animals oxidized more labeled palmitate to labeled $\mathrm{CO}_{2}$ than controls (BAUMBER and DENYES, 1965; FelT and MASORO, 1959). Increases in the oxidation rate of plasma FFA under the hormone stimulation were also significantly greater in the former than in the latter (Table 2). Similarly, average value of uptake of plasma FFA during norepinephrine infusion was $4.45 \pm 0.24 \mu \mathrm{Eq} / \mathrm{min} / 100 \mathrm{~g}$ body weight $(n=20)$ in cold-acclimated rats which was significantly greater than that of controls, $3.54 \pm 0.23(n=20)$. However, increases in the uptake under catecholamine load were not significantly different between both groups (Fig. 3). These results indicate that norepinephrine caused more enhancement in the oxidation than in the uptake of plasma FFA. In fact, percentages of oxidation to uptake of plasma FFA under norepinephrine infusion became much higher in cold- than in warm-acclimated rats (Table 3). Nevertheless, the enhanced activation of FFA oxidation in cold-acclimated rats did not accompany corresponding increases in percentage of $\mathrm{CO}_{2}$ derived from plasma FFA. This fact suggests an occurrence of simultaneous stimulation of oxidation of substrates other than plasma FFA under these conditions. Similar findings were obtained in rats even after evisceration (Table 4). All of these results indicate that norepinephrine infusion in the cold-acclimated rats stimulates more oxidation of plasma FFA than its uptake, even though both parameters were increased simultaneously. The stimulation of FFA oxidation probably occurs in muscles, since the whole pattern of changes in the parameters was not affected by evisceration.

However, before arriving at the above conclusion, we have to exclude the following possibilities. The first is whether or not the stimulatory effect of norepinephrine on the FFA oxidation may be due to its effect on blood flow. KUROSHIMA et al. (1967) showed that the cardiac output in cold-acclimated rats increased 2 -fold over controls. They also showed that intravenous infusion of norepinephrine $(2 \mu \mathrm{g} / \mathrm{min}$ for $10 \mathrm{~min}$ ) into control rats caused an 1.9-fold increase in the cardiac output, but no further increment in cold-acclimated rats. In the present study, this dose of norepinephrine did not cause a greater change of parameters in the control rat as compared with cold-acclimated rats. Therefore, it is very unlikely that the norepinephrine-induced change in hemodynamics is the cause of the enhanced oxidation observed. The second is the finding in the present study that percentages of FFA oxidation to total oxidative metabolism were much lower than in other reports (Issekutz and PAul, 1966; PAUl and Holmes, 1973). As shown in Fig. 5, continuous infusion of ${ }^{14} \mathrm{C}$-palmitate-albumin complex failed to yield a plateau in specific activity of respiratory $\mathrm{CO}_{2}$, while a plateau was observed in 10 min when ${ }^{14} \mathrm{C}$-labeled bicarbonate was infused (Fig. 2). MASIRONI and DEPO- 
CAS (1961) observed the same phenomena in conscious rats. Extensive recycling of labeled compounds in compartments which are not on the direct pathway of oxidation of FFA, such as incorporation into adipose tissue and plasma and tissue glycerides and also conversion to ketone bodies and their subsequent utilization (MAEKUBo et al., 1977), could account for this observation. In the present study, $\mathrm{CO}_{2}$ expired was trapped for five minutes from 15 to $20 \mathrm{~min}$ after the start of ${ }^{14} \mathrm{C}$ palmitate infusion, but other authors utilized the much later period. Therefore, difference in the timing of sampling would explain the difference in the percentage.

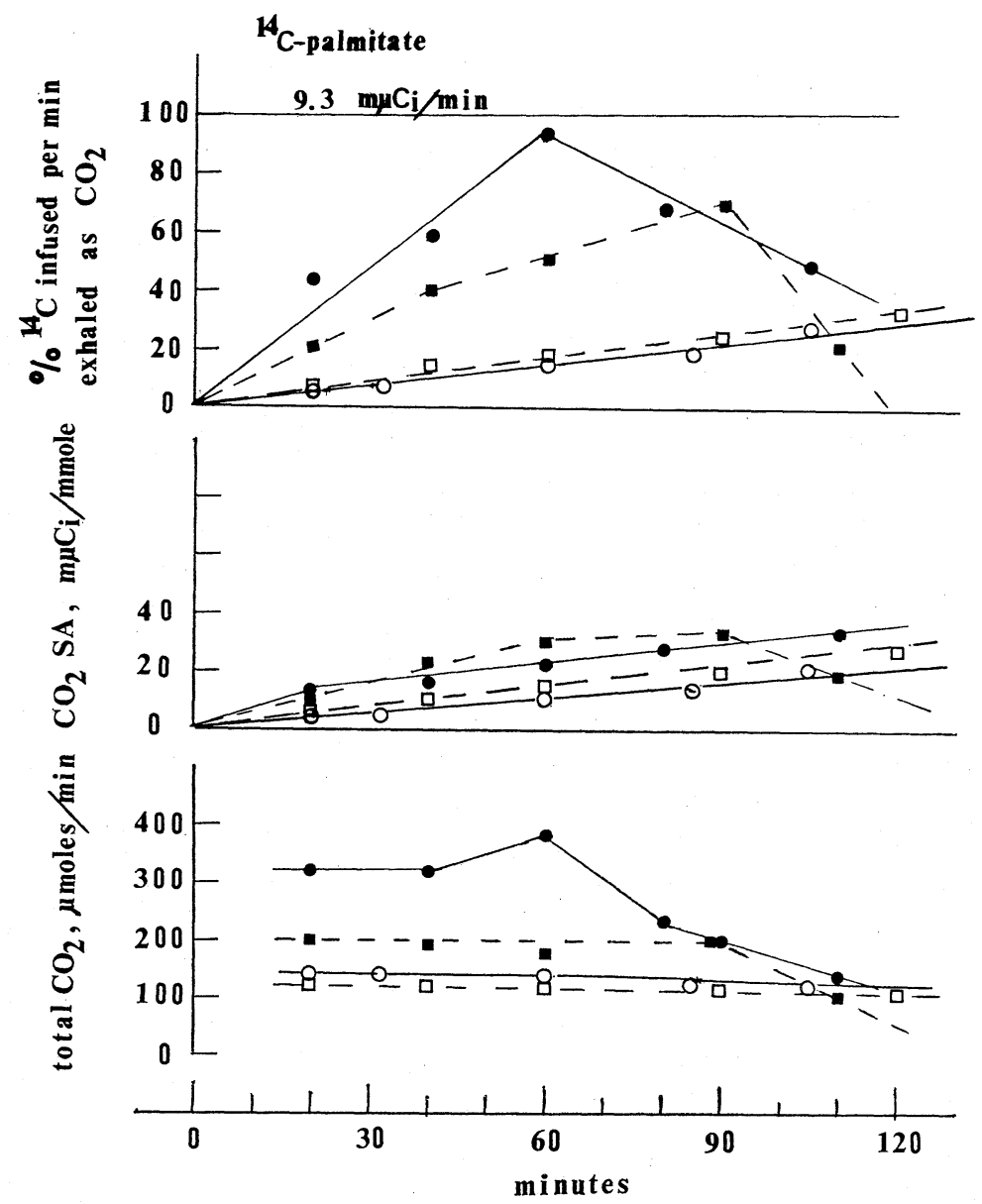

Fig. 5. Respiratory ${ }^{14} \mathrm{CO}_{2}$ production in terms of total $\mathrm{CO}_{2}, \mathrm{CO}_{2} \mathrm{SA}$ and ${ }^{14} \mathrm{CO}_{2}$ output in the exhaled air (as percentage of ${ }^{14} \mathrm{C}$ infused) during continuous intravenous infusion of ${ }^{14} \mathrm{C}$-palmitate-albumin complex to warm- $(\square, \boldsymbol{\square})$ and cold-acclimated rats $(O, \bullet)$. Open symbols represent values in the basal state under urethane anesthesia and closed symbols values during norepinephrine infusion at a rate of $2 \mu \mathrm{g} / \mathrm{min}$ into rats under pentobarbital anesthesia. 
The third is the effect of anesthetics used. These anesthetics are known to diminish cellular respiration by primarily inhibiting electron transfer in the area of $\mathrm{NADH}$ dehydrogenase and their ability of diminishing respiration in vitro relates to narcotic potency in vivo (COHEN, 1973). In fact, $\mathrm{CO}_{2}$ expiration rate in this study was almost one-half of respiration in conscious rats reported by others (TSUKADA et al., 1965; BARTUKova et al., 1970). Nevertheless, norepinephrine was shown in this study to stimulate more oxidation of plasma FFA than its uptake, even though further experiments with conscious animals would be warranted. Finally, according to MASIRONI and DEPOCAS (1961), although the oxidation rate of plasma FFA in cold-acclimated rats in conscious state was higher in environment at $6^{\circ} \mathrm{C}$ than at $30^{\circ} \mathrm{C}$, the rate at $6^{\circ} \mathrm{C}$ was not different from that in warm-acclimated rats. Since cold exposure stimulates norepinephrine release, which results in an increase in the oxidation rate of plasma FFA, their results appear difficult to interpret. However, it is possible that animals exposed acutely to cold may release more norepinephrine as well as other lipolytic hormones such as ACTH, than coldacclimated rats (LEDUC, 1961). According to HANNON and LARSON (1962), the effects of norepinephrine infusion and cold exposure on the calorigenesis were not identical. Therefore, we cannot estimate the direct effect of norepinephrine alone from their results.

On the rate-limiting step of the FFA oxidation, carnitine acyltransferase has been implicated in several studies from other laboratories (FRITZ and MARQUIS, 1965; OrAM et al., 1973). This enzyme is associated with the membrane of mitochondria which are intracellular site of FFA oxidation and respiration. When carnitine is present the enzyme allows FFA to penetrate the mitochondria so that the substrate may gain access to $\beta$-oxidation by enzyme system. Furthermore, it has been reported that in cold-acclimated rats the carnitine content increased eight times and its turnover time was one-half of the control (DELISLE and RADOMSKI, 1968; Therriault and Mehlman, 1965). Therefore, it remains to examine changes in the enzyme activity of acylcarnitine transferase in cold-acclimated animals and the influence of norepinephrine on it.

\section{REFERENCES}

Armstrong, W. D., Schubert, J., and Lindenbaum, A. (1948) Distribution of radioactive carbon administered as carbonate in the body and excrete of mature rat. Proc. Soc. Exp. Biol. Med., 68: 233-240.

Armstrong, D. T., Steel, R., Altzuler, N., Dunn, A., Bishop, J. S., and DeBodo, R. C. (1961a) Regulation of plasma free fatty acid turnover. Am. J. Physiol., 201: 9-15.

Armstrong, D. T., Steel, R., Altzuler, N., Dunn, A., Bishop, J. S., and DeBodo, R. C. (1961b) Plasma free fatty acid turnover during insulin-induced hypoglycemia. Am. J. Physiol., 201 : 535-539.

Bartukova, R., JAnsky, L., and Mejsnar, J. (1970) Nonshivering thermogenesis and cold adaptation. In: Nonshivering Thermogenesis, ed. by JANSKY, L. Swets and Zeilinger, N. V., Amsterdam, pp. 39-56. 
Baumber, J. and Denyes, A. (1965) Oxidation of glucose-U- $-{ }^{14} \mathrm{C}$ and palmitate- $1-{ }^{14} \mathrm{C}$ by liver, kidney, and diaphragm from hamsters in cold exposure and hibernation. Can. J. Biochem., 43: 747-753.

CoHen, P. J. (1973) Effect of anesthetics on mitochondrial function. Anesthesiology, 39: 153164.

Delisle, G. and Radomski, M. W. (1968) The role of carnitine in the animal exposed to cold. Can. J. Physiol. Pharmacol., 46: 71-75.

DuncomBe, W. G. (1963) The colorimetric microdetermination of long-chain fatty acids. Biochem. J., 88: 7-10.

Felt, J. M. and Masoro, E. J. (1959) Effects of cold acclimation on hepatic carbohydrate and lipid metabolism. Am. J. Physiol., 197: 34-36.

Fredrickson, C. S. and OnO, R. (1958) An improved technique for assay of ${ }^{14} \mathrm{CO}_{2}$ in expired air using the liquid scintillation counter. J. Lab. Clin. Med., 51: 147-151.

Fritz, I. B. and MARQUIS, N. R. (1965) The role of acylcarnitine esters and carnitine palmityltransferase in the transport of fatty acyl groups across mitochondria membranes. Proc. Natl. Acad. Sci. USA, 54: 1226-1233.

Hannon, J. P. and Larson, A. M. (1962) Fatty acid metabolism during norepinephrine-induced thermogenesis in the cold-acclimated rat. Am. J. Physiol., 203: 1055-1061.

Hsieh, A. C. L. and Carlson, L. D. (1957) Role of adrenaline and noradrenaline in chemical regulation of heat production. Am. J. Physiol., 190: 243-246.

Hsien, A. C. L., Carlson, L. D., and Gray, G. (1957) Role of the sympathetic nervous system in the control of chemical regulation of heat production. Am. J. Physiol., 190: 247-251.

Issekutz, B., JR., Miller, H. I., Paul, P., and Rodahl, K. (1964) Source of fat oxidation in exercising dogs. Am. J. Physiol., 207: 583-589.

Issekutz, B., JR. and PAUl, P. (1966) The role of extra-muscular energy sources in the metabolism in exercising dog. Fed. Proc., 25: 334.

Kuroshima, A., Konno, N., and Iтон, S. (1967) Increase in the blood flow through brown adipose tissue in response to cold exposure and norepinephrine in the rat. Jap. J. Physiol., 17: $523-537$.

LEDUC, J. (1961) Catecholamine production and release in exposure and acclimation to cold. Acta Physiol. Scand., Suppl. 183: 1-101.

Maekubo, H., Moriya, K., and Hiroshige, T. (1977) The role of ketone bodies in nonshivering thermogenesis in cold-acclimated rats. J. Appl. Physiol., 42: 159-165.

Masironi, R. and Depocas, F. (1961) Effect of cold exposure on respiratory ${ }^{14} \mathrm{CO}_{2}$ production during infusion of albumin-bound palmitate- $1-{ }^{14} \mathrm{C}$ in white rats. Can. J. Biochem. Physiol., 39: 219-224.

Minaire, Y., Vincent-Falquet, J. C., Pernod, A., and Chatonnet, J. (1973) Energy supply in acute cold-exposed dogs. J. Appl. Physiol., 35: 51-57.

Moriya, K., Maekubo, H., and IтоH, S. (1974) Turnover rate of plasma free fatty acids in coldacclimated rats. Jap. J. Physiol., 24: 419-431.

Oram, J. F., Bennetch, S. L., and Neely, J. R. (1973) Regulation of fatty acid utilization in isolated perfused rat hearts. J. Biol. Chem., 248: 5299-5309.

Paul, P. and Holmes, W. L. (1973) FFA metabolism in thyroidectomized and normal dogs during rest and acute cold exposure. J. Appl. Physiol., 35: 250-258.

Skipper, H. E., Bennett, L. L., Jr., Bryan, C. E., White, L., Jr., Newton, M. A., and Simpson, L. (1951) Carbamates in the chemotherapy of leukemia. VIII. Overall tracer studies on carbonyl-labeled urethan, methylene-labeled urethan, and methylene-labeled ethyl alcohol. Cancer Res., 11: 46-51.

Steinberg, D., Nestel, P. J., Buskirk, E. R., and Thompson, R. H. (1964) Calorigenic effect of norepinephrine correlated with plasma FFA turnover and oxidation. J. Clin. Invest., 
43: 167-176.

Therriault, D. G. and Mehlman, M. A. (1965) Metabolism of carnitine in cold-acclimated rats. Can. J. Biochem., 43: 1437-1443.

Therriault, D. G., Hubbard, R. W., and Mellin, D. B. (1969) Endocrine control of fat mobilization in the isolated fat cell of cold-exposed rats. Lipids, 4: 413-420.

TsukadA, M., OKuno, A, and IтоH, S. (1965) Influence of vasopressin on the metabolic rate in rats. Jap. J. Physiol., 15: 388--396. 